drini, the secretary of the commission, to the infected areas, have no doubt prompted the sending of a representative this year. By mutual agreement, a vaccinated buffer zone is being maintained along the common frontier of Russia with Poland, Czechoslovakia and Rumania. The Baltic states are completely free from the disease, and Dr Khoudiakov emphasized that there is strict inspection of meat for export. The Rumanian observer confirmed that there was excellent co-operation with the Soviet Union in maintaining vaccination in the buffer zone, with the result that Rumania was completely free of foot and mouth in 1967.

The vaccination campaigns which the commission has mounted over the past six years have prevented exotic strains of the disease from spreading from Africa and the Middle East across the Bosphorus and into south-east Europe-A22 and the African strain $S A T$ have not won a foothold, for example. In the circumstances it is unfortunate that wealthy nations such as France, Germany and the Soviet Union choose not to join the commission and contribute to its finances, which are very small at present.

At the opening of the session, the Director-General of the FAO, A. H. Boerma, congratulated the British veterinary services on their energy, self-sacrifice and endurance during the epizootic. Ironically enough, he went on to say "The steady improvement in vaccine production techniques and the increase of production capacity, as well as the extension of the application of systematic vaccination programmes in various countries, have resulted in the successful protection of the cattle population distributed over large European areas".

\section{Demand for Further Education}

Over three million students in Britain were enrolled on courses of further education in 1966, according to statistics compiled by the Department of Education and Science. This represents a 5 per cent increase since 1965.

The demand for further education has shifted from evening classes to full-time courses. The number of students taking advanced level courses leading to a qualification increased by $8 \cdot 5$ per cent between 1965 and 1966 and there was a substantial growth in enrolments for CNAA first degree courses.

The levies and grants of the Industrial Training Act were doubtless one factor behind the 39,000 students released by their employers for block release courses, as against 33,000 in 1965 , and the 625,000 students who went on day release. The Department of Education and Science has drawn up a league table showing the relative performances of various industries in terms of the number of employees under 18 years who were granted day release. The league table is topped by such industries as mining, engineering, shipbuilding and car making, which sent nearly 50 per cent or more of such employees on day release. Insurance, banking and finance come firmly bottom of the league with a mere $3 \cdot 1$ per cent.

The department comments on the "continued reluctance of employers in many sectors of industry to grant day release for women as freely as they do for men". On present figures a man under 18 has four times as great a chance of being sent on day release as a woman under 18.

\section{More Flying}

THE number of passengers using the airports in Britain exceeded 24 million in 1967, according to figures just issued by the Board of Trade. Although this represents an increase of 6 per cent over 1966, the growth rate in 1967 was lower than the average for the last four years, which has been 11 per cent. This decline was caused by a sharp fall in the number of passengers during the summer holiday season. During the second and third quarters of 1967, the increases over 1966 were 2 per cent and 5 per cent respectively, compared with 13 per cent in the first quarter and 8 per cent in the last. As in the past, well over half- 14.5 million-of the air passengers in 1967 used airports servicing London. This is very close to the $\mathbf{1 4 . 3}$ million predicted in the report on the Third London Airport published in May 1967. The total weight of freight landing and leaving British airports dropped to 490,000 tons, 6 per cent less than in 1966 but still 17 per cent more than in 1965. Again over half of this traffic was at London.

\section{Victory on Points}

THe argument over the kind of decimal marker to be used when Britain adopts the decimal system in currency and the metric system in units has been resolved in favour of the decimal point. A difference of opinion had arisen between the British Standards Institution, which favoured the use of the decimal comma, and the Decimal Currency Board, which favoured the decimal point (Nature, 217, $995 ; 1968$ ). In the absence of an international agreement, the Ministry of Technology Joint Committee on Metrication went along with the decimal currency board. Although the BSI had already stated its preference, and the construction industry had already begun the process of metrication on the basis of the decimal comma, the BSI has now backed down.

Last week the BSI said that industry had no alternative but to adopt the decimal board's recommendation. But it made it clear that the decision had been taken with regret, against its better judgment. Actually, the decision was a finely balanced one-although the comma is used in Europe, it is by no means universal. The use of two systems, although it does detract somewhat from the elegance of the international system, is unlikely to cause ambiguity. But if international agreement is reached to use the decimal comma after Britain has changed both money and units on the basis of the decimal point, it could then be much harder-and more expensive-for Britain to change.

\section{Coal Board Merger}

The National Coal Board has announced a plan to merge the activities of the Mining Research Establishment at Isleworth, Middlesex, and the Central Engineering Establishment at Stanhope Bretby, near Burton-on-Trent. The object of the merger is to increase the efficiency of research and development work and to prevent any overlap.

The Mining Research Establishment was set up in 1952 for the investigation of underground problems and was made the responsibility of the board's scientific 